\title{
Histoplasmosis in Children; HIV/AIDS Not a Major Driver
}

\author{
Bassey E. Ekeng ${ }^{1, * \mathbb{D}}$, Kevin Edem ${ }^{2}$, Ikechukwu Amamilo ${ }^{3}$, Zachary Panos ${ }^{4}$, David W. Denning ${ }^{5}$ and \\ Rita O. Oladele ${ }^{6, *}$
}

1 Department of Medical Microbiology and Parasitology, University of Calabar Teaching Hospital, Calabar 540271, Nigeria

2 Department of Paediatrics, University of Uyo Teaching Hospital, Uyo 52021, Nigeria; edemkevin@gmail.com

3 Clinton Health Access Initiative, Department of Infectious Diseases Global HIV Access Program, Abuja 900287, Nigeria; iamamilo@clintonhealthaccess.org

4 Clinton Health Access Initiative, Department of Infectious Diseases Global HIV Access Program, Washington, DC 20560, USA; zpanos@clintonhealthaccess.org

5 Global Action Fund for Fungal Infections, 1211 Geneva, Switzerland; ddenning@gaffi.org

6 Department of Medical Microbiology and Parasitology, Faculty of Basic Medical Sciences, College of Medicine, University of Lagos, Lagos 100254, Nigeria

* Correspondence: basseyewaekeng@gmail.com (B.E.E.); roladele@unilag.edu.ng (R.O.O.)

Citation: Ekeng, B.E.; Edem, K.; Amamilo, I.; Panos, Z.; Denning, D.W.; Oladele, R.O. Histoplasmosis in Children; HIV / AIDS Not a Major Driver. J. Fungi 2021, 7, 530. https:// doi.org/10.3390/jof7070530

Academic Editor:

M. Teresa Martin-Gomez

Received: 12 June 2021

Accepted: 25 June 2021

Published: 30 June 2021

Publisher's Note: MDPI stays neutral with regard to jurisdictional claims in published maps and institutional affiliations.

Copyright: (C) 2021 by the authors. Licensee MDPI, Basel, Switzerland. This article is an open access article distributed under the terms and conditions of the Creative Commons Attribution (CC BY) license (https:/ / creativecommons.org/licenses/by/ $4.0 /)$.

\begin{abstract}
The classification of histoplasmosis as an AIDS-defining illness has largely attributed its occurrence in people to the presence of HIV / AIDS especially in Africa. Prior to the advent of the HIV / AIDS epidemic, many cases of histoplasmosis were documented both in the pediatric and adult population. Our review revealed 1461 reported cases of pediatric histoplasmosis globally in the last eight decades (1939-2021). North America $(n=1231)$ had the highest number of cases, followed by South America $(n=135)$, Africa $(n=65)$, Asia $(n=26)$ and Europe $(n=4)$. Histoplasmosis was much more common in the non-HIV pediatric population $(n=1418,97.1 \%)$ compared to the HIV population. The non-HIV factors implicated were, childhood malignancies $(n=207)$, such as leukemias and lymphomas as well as their treatment, lung diseases $(n=7)$, environmental exposures and toxins $(n=224)$, autoimmune diseases $(n=12)$, organ transplants $(n=12)$, long-term steroid therapy $(n=3)$, the use of immunosuppressive drugs such as TNF-alpha inhibitors $(n=7)$ malnutrition $(n=12)$, histiocytosis $(n=3)$, hyperimmunoglobulin $\mathrm{M}$ and $\mathrm{E}$ syndromes $(n=15,1.2 \%)$, pancytopaenias $(n=26)$, diabetes mellitus $(n=1)$ and T-cell deficiency $(n=21)$. Paediatricians should always consider or rule out a diagnosis of histoplasmosis in children presenting with symptoms suggestive of the above clinical conditions.
\end{abstract}

Keywords: histoplasmosis; children; low medium countries; HIV; childhood malignancies; immunosuppressants

\section{Introduction}

Histoplasmosis is a systemic fungal infection occurring globally. It is endemic in the Ohio and Mississippi river valleys of the United States of America, India and Southeast Asia [1,2]. The clinical presentation of histoplasmosis mimics features seen in tuberculosis (TB) and may be misdiagnosed as such [3]. Amongst risk factors associated with disseminated histoplasmosis (DH), HIV infection has been attributed as the greatest factor predisposing patients to $\mathrm{DH}$ in the adult population [4]. However, before the advent of HIV / AIDS, several cases of DH had been reported [5]. Additionally, a review on the documented cases of histoplasmosis in Africa, from 1952-2017 by Oladele et al. revealed 37 cases of histoplasmosis in the pediatric age group, of which 33 (89.2\%) were non-HIV patients [4]. In another report by Arango et al. of the Colombian National Survey, 1992-2008, 17 cases of histoplasmosis were reported within the pediatric age group, two were patients with AIDS, four had hematological cancers, three had environmental exposures, while eight had unknown risk factors [6]. In yet another study on childhood histoplasmosis by Lopez 
et al. from 1984 to 2010, of the total 45 cases found, only four cases were HIV positive patients [7]. The other cases were attributed to malnutrition, tumors and environmental exposure [7]. Pakasa et al., in a case series study also revealed a high incidence $(41.744 .4 \%$, 15/36) of histoplasmosis in non-HIV children within the age range of 3-16 years [8]. A large percentage of histoplasmosis in the pediatric age group most likely occurs in the non-HIV population, despite being described as an AIDS-defining illness. The purpose of this review is to identify factors other than HIV infection predisposing children to histoplasmosis and to raise awareness on pediatric histoplasmosis in the non-HIV population.

\section{Mycology Summary}

Histoplasmosis is caused by the dimorphic fungus, Histoplasma capsulatum. The two varieties pathogenic to humans are $H$. capsulatum var. capsulatum and $H$. capsulatum var. duboisii. The third variety, H. capsulatum var. farciminosum, is an equine pathogen [2]. However, a new taxonomic rearrangement of H. capsulatum proposed by Sepúlveda VE et al. showed that it is composed of at least four different cryptic species that differ genetically and also in virulence: Histoplasma capsulatum (Panama or H81 lineage), Histoplasma mississippiense (NAm 1), Histoplasma ohiense (NAm 2) and Histoplasma suramericanum (LAm A) [2]. Human infection occurs by inhalation of microconidia and short hyphal fragments which are converted into yeast forms in the alveoli. Transmission can also be orally, causing infection in the intestines [9]. Transplacental, congenital and perinatal transmission of infections have also been reported [10-14]. Histoplasmosis is primarily a pulmonary disease but can be disseminated in individuals at the extremes of ages due to their weak immune system, in people with advanced HIV/AIDS disease and secondary to persistent exposures to Histoplasma conidia [2,15]. Extrapulmonary presentation involving the skin may also occur and may progress to cause bone damage [3].

\section{Materials and Methods}

Literature searches for publications on histoplasmosis in children preceding February 2021 were performed using PubMed, Google Scholar, AJOL, Cochrane Library, Africa-Wide: NiPAD, CINAHL (accessed via EBSCO Host) databases and grey literature to identify all published papers regarding the topic. The main search comprised individual searches using detailed medical subject heading terms for histoplasmosis in children, including broad terms such as "case reports of histoplasmosis in children" and/or 'diagnosis' and 'management' of histoplasmosis in children. References in all relevant papers were also reviewed for additional publications ('snow balling') on histoplasmosis in children that may not have been published in the searched databases. No language restriction was applied. Only reports with patients' country of origin identified were included. Publications reporting cases of histoplasmosis in individuals greater than 18 years of age were excluded from the review, as well as studies involving histoplasmosis in non-humans. Publications without abstracts were also excluded. The case definitions employed were based on an international consensus statement by the European Organization for Research and Treatment of Cancer/Invasive Fungal Infections Cooperative Group (EORTC/IFICG) and the Mycoses Study Group (MSG) [16]. Case reports with undefined HIV status were assumed to be negative while case reports with defined HIV status (that is positive or negative) were documented as such.

\section{Results}

Histoplasmosis in children has been reported globally with high endemicity in Northern and Southern America [5,17]. Our literature search revealed a total of 1461 documented cases of histoplasmosis in children reported globally (Table 1) dating from 1945 to 2021. The number of cases were highest in North America $(n=1231)$, with $76.7 \%(944 / 1231)$ occurring in the USA. Very few cases $(n=4)$ in the pediatric population have been reported in Europe and were found in immigrants from endemic regions [18-20]. The number of documented cases from other climes were, South America $(n=135)$, Africa $(n=65)$ and Asia 
( $n=26)$ respectively. More cases occurred in the non-HIV population compared to the HIV population, globally. The percentages of non-HIV patients with pediatric histoplasmosis across the various regions was 97.1\% (1418/1461) and North America $(96.8 \%, 1192 / 1231)$, South America (99.3\%, 134/135), Africa (98.5\%, 64/65), Asia (96.2\%, 25/26) within each region, respectively, Table 1, Figure 1. Pediatric histoplasmosis in America and China were caused by Histoplasma capsulatum var capsulatum (Hcc), while in Africa, it was largely due to Histoplasma capsulatum var duboisii (Hcd) $(88.7 \%$, 47/53). Most cases of disseminated histoplasmosis occurred in persons with compromised immunity (Table 2) [21,22]. These infections are also common at the extremes of age, i.e., in infants and the elderly, although cases of disseminated histoplasmosis have been reported in apparently normal individuals without the usual risk factors of extremes of age or some form of immunosuppression $[23,24]$. Childhood cancers such as leukemias and lymphomas as well as their treatment may predispose to histoplasmosis [21]. Underlying lung diseases, environmental exposures and toxins, autoimmune disease, long-term steroid therapy, use of immunosuppressive drugs such as TNF-alpha inhibitors may also predispose to histoplasmosis in children who are HIV-negative. Other less common conditions include histiocytosis, hyperimmunoglobulin $\mathrm{M}$ and $\mathrm{E}$ syndromes and pancytopaenias (Tables 1-3) [21,22]. DH has also been documented in both premature and mature infants with variable outcomes [25-29].

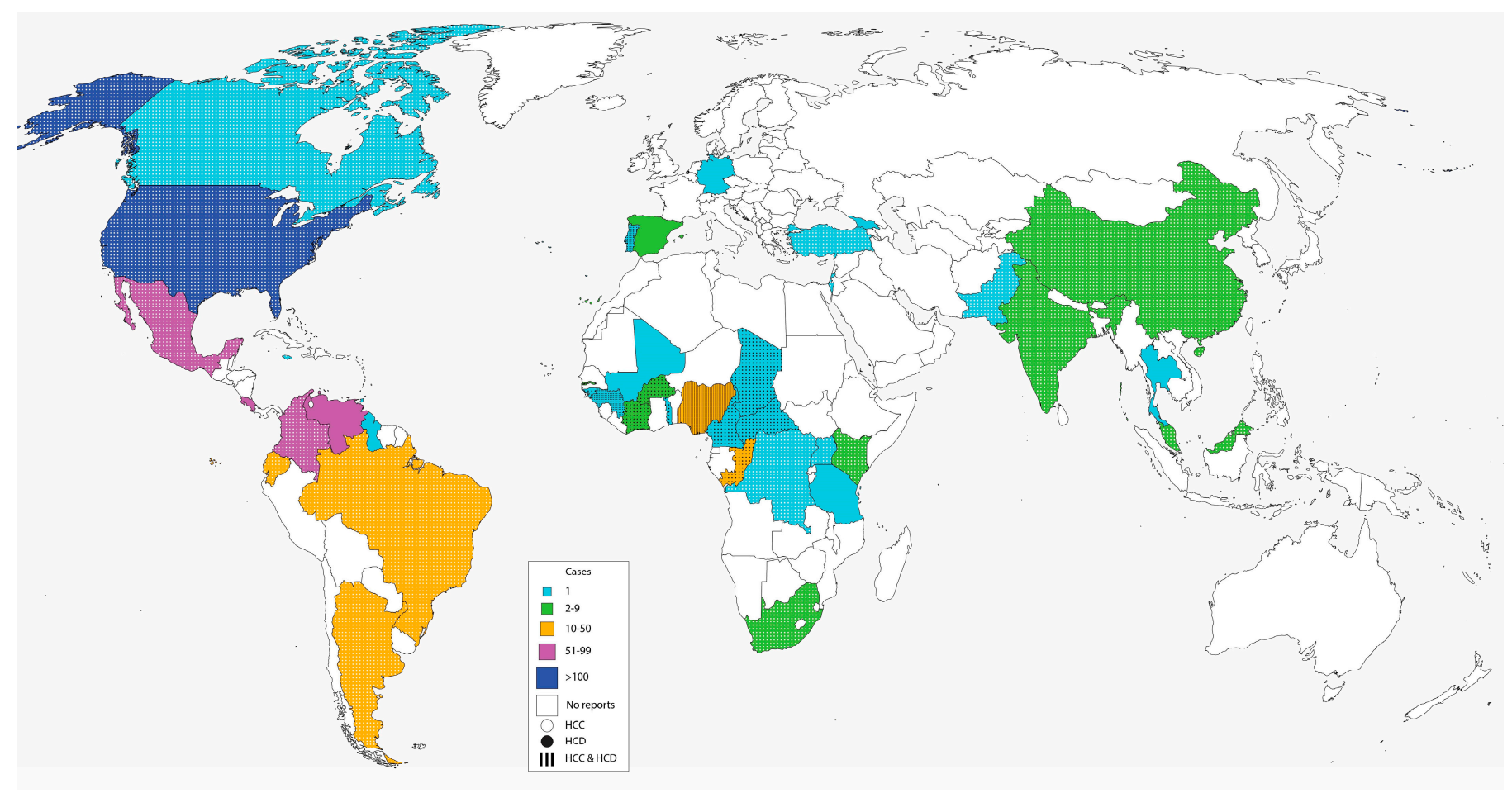

Figure 1. Global distribution of histoplasmosis in children. 
Table 1. Global distribution of Pediatric histoplasmosis.

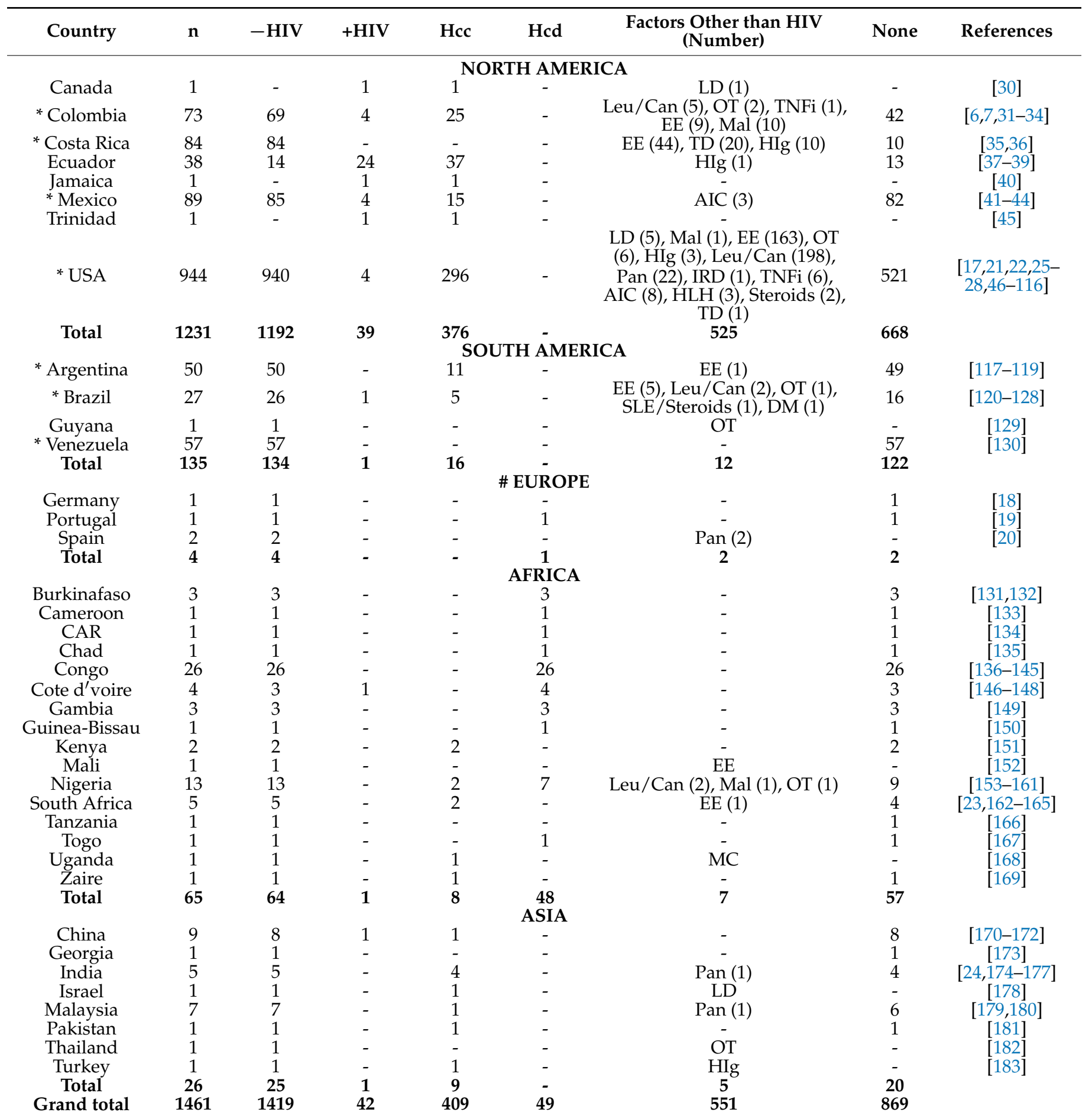

n, number of cases; HIV, Human immunodeficiency virus; Hcc, Histoplalsma capsulatum var capsulatum; Hcd, Histoplasma capsulatum var duboisii; LD, Lung diseases; Leu/Can, Leukemia and Cancers; DM, Diabetes mellitus; OT, Organ transplant; TNFi, Tumor necrosis factor inhibitors; EE, Environmental exposures; Mal, Malnutrition; TD, T cell deficiency, HIg, Hyperimmunoglobulinemia; IRD, Interferon-gamma Receptor-1 Deficiency; hemophagocytic lymphohistiocytosis (HLH); Pan, Pancytopenia; MC, mesenteric cyst: CAR, Central African Republic; \# all documented case reports were in patients that immigrated from endemic regions * Majority of diagnoses were based on serological data. 
Table 2. Percentages of non-HIV factors predisposing to pediatric histoplasmosis.

\begin{tabular}{ccc}
\hline Factors & Number of Cases & \% \\
\hline Environmental exposure & 224 & 15.8 \\
Leukaemia/Cancers & 207 & 14.6 \\
Pancytopaenia & 26 & 1.8 \\
T cell deficiency & 21 & 1.5 \\
Hyperimmunoglobulinemia & 15 & 1.1 \\
Organ transplant & 12 & 0.8 \\
Malnutrition & 12 & 0.8 \\
Tumour necrosing factor inhibitors & 7 & 0.5 \\
Lung diseases & 7 & 0.5 \\
Autoimmune conditions (SLE, Rheumatoid arthritis) & 11 & 0.8 \\
hemophagocytic lymphohistiocytosis & 3 & 0.2 \\
Steroids & 3 & 0.14 \\
Interferon-gamma Receptor 1 Deficiency & 1 & 0.07 \\
Mesenteric cyst & 1 & 0.07 \\
Diabetes mellitus & 1 & 0.07 \\
\hline Total & $\mathbf{5 5 1}$ & $\mathbf{3 8 . 8} \%$ \\
\hline
\end{tabular}

$\%=$ number of cases / total number of non-HIV cases (1419).

Table 3. Some case reports on pediatric histoplasmosis associated with non-HIV factors.

\begin{tabular}{|c|c|c|c|c|c|c|c|}
\hline Authors & $\begin{array}{l}\text { Case } \\
\text { Patients } \\
\text { (n) }\end{array}$ & $\begin{array}{l}\text { Age/Sex/ } \\
\text { Country }\end{array}$ & $\begin{array}{l}\text { Non-HIV } \\
\text { Factors }\end{array}$ & $\begin{array}{l}\text { Clinical } \\
\text { Findings }\end{array}$ & Diagnostic Method & $\begin{array}{l}\text { Treatment and } \\
\text { Clinical } \\
\text { Course }\end{array}$ & OC \\
\hline $\begin{array}{l}\text { Hess et al., } \\
\quad 2017\end{array}$ & 1 & $\begin{array}{c}\text { 11-year- } \\
\text { old/Male/USA }\end{array}$ & T-cell ALL & $\begin{array}{l}\text { fever, malaise, } \\
\text { and weight } \\
\text { loss }\end{array}$ & $\begin{array}{l}\text { CT scan: mediastinal } \\
\text { adenopathy. Bone } \\
\text { marrow: } \\
\text { pancytopenia, } \\
\text { noncaseating } \\
\text { granulomas. Urine } \\
\text { and serum } \\
\text { histoplasma antigen } \\
\text { was positive. } \\
\text { Histology of bone } \\
\text { marrow aspirate was } \\
\text { in keeping with DH }\end{array}$ & $\begin{array}{l}\text { AmB therapy. } \\
\text { Histoplasma } \\
\text { antigen in } \\
\text { urine and } \\
\text { serum was } \\
\text { undetected } \\
\text { after } 3 \text { months } \\
\text { of therapy. }\end{array}$ & $\mathrm{R}$ \\
\hline Tu et al., 1991 & 2 & $\begin{array}{c}\text { 3-year- } \\
\text { old/Male/USA }\end{array}$ & $\begin{array}{l}\text { hyper-lgM } \\
\text { syndrome }\end{array}$ & $\begin{array}{l}\text { fever, nausea, } \\
\text { vomiting, } \\
\text { stomatitis of } \\
\text { the gingiva, } \\
\text { abdominal } \\
\text { pain, fatigue, } \\
\text { and irritability. }\end{array}$ & $\begin{array}{l}\text { Disseminated } \\
\text { histoplasmosis was } \\
\text { diagnosed by bone } \\
\text { marrow biopsy and } \\
\text { culture of } \\
\text { esophageal biopsy }\end{array}$ & $\begin{array}{c}\text { Amphotericin } \\
\text { B therapy }\end{array}$ & NR \\
\hline $\begin{array}{l}\text { Yilmaz et al., } \\
1995\end{array}$ & 3 & $\begin{array}{l}\text { 3-year- } \\
\text { old/Male/ } \\
\text { Turkey }\end{array}$ & $\begin{array}{l}\text { Hyper-IgM } \\
\text { syndrome }\end{array}$ & $\begin{array}{l}\text { Recurrent } \\
\text { pulmonary } \\
\text { infections, } \\
\text { ulcerated } \\
\text { lesion of about } \\
10 \mathrm{~cm} \text { on the } \\
\text { left side of the } \\
\text { face }\end{array}$ & $\begin{array}{c}\text { IgM, } 1380 \mathrm{mg} / \mathrm{dl} \text {. } \\
\text { Chest radiograph } \\
\text { showed bilateral } \\
\text { infiltration and } \\
\text { bronchiectasis. } \\
\text { Biopsy of skin lesion } \\
\text { revealed } \\
\text { intracellular yeast } \\
\text { cells }\end{array}$ & $\begin{array}{l}\text { ketoconazole } \\
10 \mathrm{mg} / \mathrm{kg} / \text { day, } \\
\text { with im- } \\
\text { munoglobulin } \\
\text { therapy }\end{array}$ & $\mathrm{R}$ \\
\hline
\end{tabular}


Table 3. Cont.

\begin{tabular}{|c|c|c|c|c|c|c|c|}
\hline Authors & $\begin{array}{c}\text { Case } \\
\text { Patients } \\
\text { (n) }\end{array}$ & $\begin{array}{l}\text { Age/Sex/ } \\
\text { Country }\end{array}$ & $\begin{array}{l}\text { Non-HIV } \\
\text { Factors }\end{array}$ & $\begin{array}{l}\text { Clinical } \\
\text { Findings }\end{array}$ & Diagnostic Method & $\begin{array}{l}\text { Treatment and } \\
\text { Clinical } \\
\text { Course }\end{array}$ & OC \\
\hline $\begin{array}{l}\text { Hess et al., } \\
\quad 2017\end{array}$ & 4 & $\begin{array}{c}\text { 14-Year- } \\
\text { old/Male/USA }\end{array}$ & $\begin{array}{l}\text { Desmoplastic } \\
\text { small round } \\
\text { cell tumor of } \\
\text { the abdomen }\end{array}$ & $\begin{array}{l}\text { Persistent fever } \\
\text { and } \\
\text { neutropenia }\end{array}$ & $\begin{array}{c}\text { Chest CT } \\
\text { demonstrated a } \\
\text { solitary calcified } \\
\text { lung nodule. } \\
\text { Histoplasma } \\
\text { serology became } \\
\text { positive with } \\
\text { increasing titers of } \\
\text { histoplasmosis yeast } \\
\text { by complement } \\
\text { fixation from 1:16 to } \\
\text { 1:32. Diagnosis was } \\
\text { pulmonary } \\
\text { histoplasmosis }\end{array}$ & $\begin{array}{l}\text { Itraconazole, } \\
\text { Posaconazole } \\
\text { and AmB were } \\
\text { used for } \\
\text { therapy }\end{array}$ & NR \\
\hline $\begin{array}{l}\text { Tschudy } \\
\text { et al., } 2010\end{array}$ & 5 & $\begin{array}{l}\text { 8-year- } \\
\text { old/Male/ } \\
\text { USA }\end{array}$ & $\begin{array}{l}\text { Crohn Dis- } \\
\text { ease/Infliximab } \\
\text { therapy }\end{array}$ & $\begin{array}{l}\text { fevers, cough, } \\
\text { anorexia, and } \\
\text { night sweats. }\end{array}$ & $\begin{array}{c}\text { Urine histoplasma } \\
\text { antigen test: positive. } \\
\text { Fungal culture grew } \\
\text { Histoplasma } \\
\text { capsulatum from } \\
\text { lymph node biopsy. } \\
\text { Histoplasmosis } \\
\text { antibodies to both } \\
\text { yeast and mycelia } \\
\text { returned elevated } \\
\text { (1:1024 yeast and } \\
1: 16 \text { mycelia). } \\
\text { Bronchoscopic }\end{array}$ & $\begin{array}{l}\text { Itraconazole } \\
\text { (6 mg/kg/day, } \\
\text { divided twice } \\
\text { per day) }\end{array}$ & $\mathrm{R}$ \\
\hline $\begin{array}{l}\text { Zerbe et al., } \\
\quad 2005\end{array}$ & 6 & $\begin{array}{c}3 \text { years and } 8 \\
\text { months / } \\
\text { Male/USA }\end{array}$ & $\begin{array}{l}\text { Interferon-g } \\
\text { Receptor } 1 \\
\text { Deficiency }\end{array}$ & $\begin{array}{l}\text { Recurrent fever, } \\
\text { hep- } \\
\text { atosplenomegaly, } \\
\text { left cervical } \\
\text { adenopathy }\end{array}$ & $\begin{array}{l}\text { washings, a sputum } \\
\text { specimen, and a } \\
\text { bone marrow } \\
\text { aspirate all grew } H . \\
\text { capsulatum. Genetic } \\
\text { studies showed } \\
\text { 818del4 deletion in } \\
\text { IFNGR1, which } \\
\text { leads to autosomal } \\
\text { dominant } \\
\text { IFN-gamma receptor } \\
\text { deficiency }\end{array}$ & $\begin{array}{c}\text { Subcutaneous } \\
\text { treatment with } \\
\text { IFN-gamma } \\
\left(50 \mu \mathrm{g} / \mathrm{m}^{2}\right) \\
\text { was given } 3 \\
\text { times/week. } \\
\text { Oral } \\
\text { ketoconazole } \\
\text { therapy }\end{array}$ & $\mathrm{R}$ \\
\hline $\begin{array}{l}\text { Hess et al., } \\
2017\end{array}$ & 7 & $\begin{array}{l}\text { 6-year- } \\
\text { old/Male/ } \\
\text { USA }\end{array}$ & B-Cell ALL & $\begin{array}{l}\text { nonspecific } \\
\text { fever }\end{array}$ & $\begin{array}{l}\text { Blood culture was } \\
\text { positive for } \\
\text { Histoplasma } \\
\text { capsulatum. Chest } \\
\text { CT: right hilar } \\
\text { adenopathy. } \\
\text { Antigenuria and } \\
\text { antigenemia were } \\
\text { confirmed. } \\
\text { Diagnosis was DH }\end{array}$ & $\begin{array}{l}\text { AmB for } \\
14 \text { days } \\
\text { followed by } \\
\text { itraconazole. }\end{array}$ & $\mathrm{R}$ \\
\hline $\begin{array}{l}\text { Hess et al., } \\
\quad 2017\end{array}$ & 8 & $\begin{array}{l}\text { 8-year- } \\
\text { old/Male/ } \\
\text { USA }\end{array}$ & $\begin{array}{l}\text { Stage II } \\
\text { abdominal } \\
\text { Burkitt } \\
\text { lymphoma }\end{array}$ & $\begin{array}{c}\text { Fever and } \\
\text { neutropenia }\end{array}$ & $\begin{array}{l}\text { Histoplasma } \\
\text { serology was } \\
\text { positive. Diagnosis } \\
\text { was pulmonary } \\
\text { histoplasmosis. }\end{array}$ & $\begin{array}{l}\text { Itraconazole } \\
\text { therapy }\end{array}$ & $\mathrm{R}$ \\
\hline $\begin{array}{l}\text { Ferguson- } \\
\text { Pau et al., } \\
\quad 2018\end{array}$ & 9 & $\begin{array}{l}\text { 18-year-old/ } \\
\text { Female/ } \\
\text { USA }\end{array}$ & $\begin{array}{l}\text { Kidney } \\
\text { transplant }\end{array}$ & $\begin{array}{l}\text { Fever, chest } \\
\text { pain, weight } \\
\text { loss, malaise, } \\
\text { headache, and } \\
\text { myalgias } \\
\text { post-renal } \\
\text { transplant }\end{array}$ & $\begin{array}{l}\text { Urine histoplasma } \\
\text { antigen was positive } \\
\text { at } 10.69 \mathrm{ng} / \mathrm{mL}\end{array}$ & $\begin{array}{l}\text { Itraconazole } \\
\text { therapy }\end{array}$ & $\mathrm{R}$ \\
\hline
\end{tabular}


Table 3. Cont.

\begin{tabular}{|c|c|c|c|c|c|c|c|}
\hline Authors & $\begin{array}{c}\text { Case } \\
\text { Patients } \\
\text { (n) }\end{array}$ & $\begin{array}{l}\text { Age/Sex/ } \\
\text { Country }\end{array}$ & $\begin{array}{l}\text { Non-HIV } \\
\text { Factors }\end{array}$ & $\begin{array}{l}\text { Clinical } \\
\text { Findings }\end{array}$ & Diagnostic Method & $\begin{array}{l}\text { Treatment and } \\
\text { Clinical } \\
\text { Course }\end{array}$ & OC \\
\hline $\begin{array}{l}\text { Ferguson- } \\
\text { Pau et al., } \\
\quad 2018\end{array}$ & 10 & $\begin{array}{c}\text { 16-year- } \\
\text { old/Female/ } \\
\text { USA }\end{array}$ & $\begin{array}{l}\text { Kidney } \\
\text { transplant }\end{array}$ & $\begin{array}{c}\text { Fever, } \\
\text { vomiting, } \\
\text { diarrhea and } \\
\text { weight loss. }\end{array}$ & $\begin{array}{l}\text { Pericardial fluid and } \\
\text { bronchoalveolar } \\
\text { lavage were } \\
\text { histoplasma } \\
\text { antigen-positive. } \\
\text { Both serum and } \\
\text { urine histoplasma } \\
\text { antigens were } \\
\text { positive above the } \\
\text { upper limit of } \\
\text { quantification. }\end{array}$ & $\begin{array}{l}\text { Amb initially } \\
\text { and } \\
\text { Itraconazole } \\
\text { thereafter }\end{array}$ & LTF \\
\hline
\end{tabular}

$R$, recovered; NR, not revealed; LTF, lost to follow up; OC, outcome.

\section{Discussion}

\subsection{Pulmonary Histoplasmosis and TB}

Histoplasmosis may be misdiagnosed as TB due to the similarities in their clinical presentation [3]. Mosam et al., 2006 reported a case of disseminated histoplasmosis in an 11-year-old female African child who initially received anti-Koch's regimen for two weeks despite negative Mantoux test and negative AFB [3]. Additionally, though rare in the literature, cooccurrence of histoplasmosis and TB has also been documented in the pediatric age group [150]. Clinicians should investigate more with respect to histoplasmosis when seeing this cohort of patients.

\subsection{Cancers}

Pediatric cancers are probably the commonest predisposing factor to histoplasmosis infection in non-HIV patients. Conversely disseminated histoplasmosis can present with pancytopenia, and be initially mistaken for leukaemia or aplastic anaemia. The presentation may be localized i.e., pulmonary disease or may be disseminated although the latter appears to be commoner [21,61]. Most children have an underlying hematologic malignancy (leukemia or lymphoma) and the diagnosis of histoplasmosis may be challenging due to the similarity in appearance of pulmonary histoplasmosis to lung metastases of primary malignancies [21]. A lung biopsy may be required to distinguish the two [22]. The impairment of T-cell function in malignancies is the pathogenetic mechanism for the increase in susceptibility to histoplasmosis in pediatric cancer patients [35,36]. The use of chemotherapeutic agents resulting in bone marrow depression and consequently predisposing the children to histoplasmosis and other opportunistic infections is another pathogenetic explanation for the increased incidence [21]. A 14-year review of 57 pediatric cancer patients by Adderson revealed that there were 61 episodes of histoplasmosis in the group with disseminated histoplasmosis being more common [61]. Fever was the most common presenting symptom and no mortalities were attributable to histoplasmosis but cancer therapy was often delayed or modified due to the infection. Most patients initially received unnecessary antibiotic therapy and they were mostly non-neutropenic. Hess et al. found that urine antigen detection was highly sensitive for disseminated disease in oncology patients but lacked sensitivity in patients with acute pulmonary disease and if utilized alone may lead to missed diagnoses [21].

\subsection{Lung Diseases}

Pediatric histoplasmosis most frequently manifests as an acute pulmonary disease [57]. In adults, pulmonary histoplasmosis affect individuals with underlying lung disease such as emphysema and less commonly chronic bronchitis [151]. Pulmonary histoplasmosis has also been reported in individuals previously diagnosed with or treated for tuberculosis [151]. Asthma, the commonest chronic lung disorder of childhood is thought to 
predispose to pulmonary histoplasmosis with possible pathogenetic mechanisms including alterations in local immunity of the respiratory tract and chronic use of corticosteroid treatments [181]. The differential diagnosis should be considered in children with asthma who present with recurrent or prolonged symptoms and who have been exposed to Histoplasma, as endemic areas and bat caves [181].

\subsection{Environmental Exposure}

Most cases of histoplasmosis in healthy children result in a clinically inapparent infection. Immunocompromised hosts, infants and the elderly may present with clinical and often disseminated disease [113]. The size of the inoculum which is a function of the degree of exposure is also implicated in the tendency to develop clinical infections. Daubenton et al. reported a case of a seven-year-old immunocompetent child who lived on a poultry farm and developed disseminated histoplasmosis [23]. Although the relevant environmental exposure considered had been exposure to bat caves, non-cave exposures werehave also been reported [23]. For instance, Haselow et al. reported that 12 children age range of 4-19 years had contracted histoplasmosis after attending a family bonfire which used bamboo retrieved from a large red blackbird roost [90]. Seven of the children were ill enough to require admission but there were no reported fatalities. The large 'inoculating dose' $^{\prime}$ and the age of the children were probably important factors in the spread of the disease in the case.

\subsection{Malnutrition}

Malnutrition is strongly associated with pediatric morbidity and mortality. The World Health Organization reported in 2020 that malnutrition was a contributing factor in $45 \%$ of all mortalities in under-five children worldwide [184]. Malnutrition is the primary cause of immunodeficiency worldwide and young children and the elderly are most affected [185]. Malnutrition leads to defects in both innate and acquired immunity and sets off a vicious cycle with malnutrition leading to poor immunity and increased risk of infections/more severe infections which will then lead to poor intake, increased metabolic demand for nutrients leading to even more malnutrition. Defects in cell-mediated immunity caused by malnutrition also predispose to histoplasmosis. Mata-Essayag et al., in a retrospective review of 158 cases of histoplasmosis in Venezuela noted that 6 out of 42 children (14.3\%) with histoplasmosis were also malnourished [130]. Of these, four (67\%) died [130]. Lopez et al., in a study of 45 Colombian children with histoplasmosis found that malnutrition was the most important risk factor being found in $37 \%$ of the patients [7]. In an earlier study by Jimenez et al., malnutrition was an association in over two-thirds of children with disseminated histoplasmosis. The mortality rate in the study was $61 \%$ [41].

\subsection{Organ Transplant}

Organ transplant recipients are susceptible to infections due to the chronic use of immunosuppressive therapy [92]. While viral infections are far commoner in solid organ transplant recipients, fungal infections are usually more serious [50]. Studies have reported on occurrences of disseminated histoplasmosis in pediatric kidney transplant patients which are by far the commonest solid organ transplants done in the pediatric age group [92,94]. Hemophagocytic lymphohistiocytosis has often been reported in association with histoplasmosis infection in kidney transplant recipients and this complicates the management and often worsens the prognosis $[50,92,94]$. A case series of six pediatric kidney transplant patients in an endemic region of the USA put the attack rate of histoplasmosis among kidney transplant patients at 6.9/100 cases. One-third of the cases occurred in the first year following the kidney transplant and there were no fatalities [94]. Most of the patients were treated with amphotericin B and then transitioned to an azole, with 83\% receiving chronic suppression therapy with itraconazole to prevent future occurrences, such therapy was usually given indefinitely. The authors suggested there may be a case for histoplasmosis prophylaxis for pediatric transplant recipients in endemic areas [94]. 


\subsection{Autoimmune Diseases/Steroid Therapy}

Pediatric autoimmune diseases like juvenile rheumatoid arthritis (JRA) are frequently treated with steroids and other immunosuppressive agents including methotrexate. Because of the low doses used, opportunistic infections are not very common in association with autoimmune steroid or immunosuppressive therapy [102]. Hunstad et al. reported a case of a seven-year-old female with JRA who developed histoplasmosis while on low-dose methotrexate. She had also recently been weaned off prednisolone treatment [102]. The authors also noted that histoplasmosis and other opportunistic infections (OIs) were less common in JRA patients receiving low-dose methotrexate than in adult patients receiving the same for rheumatoid arthritis. The rarity of fungal opportunistic infections such as histoplasmosis has also been noted among pediatric patients with Systemic Lupus Erythematosus (SLE) with the first case report of histoplasmosis diagnosed in a child with SLE being as recent as 2012 [121]. The patient in question presented with abdominal distension, splenomegaly and multiple mesenteric lymph nodes and unfortunately died of septic shock while undergoing treatment. While these reports are rare, the increasing number of children being diagnosed with autoimmune disorders and on treatment with steroids and immunosuppressive agents makes a case for pediatricians and rheumatologists to be vigilant in identifying such cases so outcomes can be improved.

\subsection{Pancytopaenia/Defective Phagocytic Function}

Pancytopaenia and defective phagocytic function usually in association with haemophagocytic lymphohistiocytosis (HLH) has been noted as a predisposing factor to pediatric histoplasmosis with Russ et al. reporting a case of histoplasmosis and HLH in a sevenmonth-old infant with vomiting and failure to thrive [186]. The report noted that the child lacked homozygosity for HLH or had an underlying immunodeficiency, and suggested that alterations in T-cell function increased her risk for HLH following the infection with histoplasmosis, although it was unclear which condition occurred first [186]. Children with defective T- and B-cell function as well as a defective phagocytic function also present with fungal opportunistic infections such as disseminated histoplasmosis. Such reports are not common in literature and are mostly from the developed world, possibly due to better diagnostic facilities. Hasliza et al. reported a case of disseminated histoplasmosis in a two-year-old previously healthy child. The workup during the illness identified gross leucopenia with defective T-cell and phagocyte function [179]. The T-cell and phagocyte function were all found to have normalized three months after the illness.

\subsection{Tumor Necrosis Factors Inhibitors}

Tumor necrosis factor-alpha (TNF-alpha) inhibitors such as adalimumab, infliximab and etanercept are commonly used in the treatment of pediatric inflammatory bowel disease $[49,78]$. They may also be used as second-line agents for auto-immune disorders of childhood such as JRA and psoriasis. However, inhibition of the TNF-alpha pathway results in a predisposition to severe infections including histoplasmosis, which is the commonest invasive fungal infection in patients on TNF-alpha therapy [78]. Dotson et al. reviewed five cases of histoplasmosis in children receiving either infliximab or adalimumab for Crohn's disease and noted that early diagnosis with discontinuation of anti-TNF medication as well as close follow-up were key to achieving good outcomes [49]. The study did not however recommend screening for latent histoplasmosis before commencing anti-TNF alpha drugs. Another report in an eight-year-old male with Crohn's disease on Infliximab who presented with histoplasmosis and concurrent Pneumocystis pneumonia further raised the issue of pre-commencement screening for opportunistic infections in children receiving TNF-alpha inhibitors [49].

\subsection{Syndromes (Hyperimmunoglobulin E Syndrome, Hyperimmunoglobulin M Syndrome)}

Hyperimmunoglobulin E syndrome also known as Job's syndrome and hyperimmunoglobulin $\mathrm{M}$ syndrome are associated with defects in immune function specifically 
with defects in immunoglobulin levels, neutrophil chemotactic defects, defects in T-cell signaling and cytokine abnormalities [74,83]. Impaired Th 17 cell differentiation is an immune defect consistently found in in the STAT3 Job's syndrome mutation and this mutation impairs protection against invasive fungal infections including histoplasmosis [74,83]. Case reports from pediatric patients have shown that both syndromes are associated with pulmonary, disseminated [74,83], and even cutaneous histoplasmosis infection [184].

\section{Conclusions}

This study has revealed the high occurrence rate of histoplasmosis in the non-HIV pediatric population, a disease commonly described as an AIDS-defining infection. We have also documented the underlying condition more commonly associated with this disease in children. Misdiagnosis of histoplasmosis as tuberculosis due to their similar pattern of presentation has also been emphasized. Physicians managing children with risk factors highlighted in this study and presenting symptoms suggestive of TB should be screened to exclude or include histoplasmosis.

Author Contributions: R.O.O. and B.E.E. were involved in the conception, design of the study and drafted the initial manuscript; B.E.E. and K.E. reviewed the literature and wrote the manuscript; D.D., R.O.O., I.A. and Z.P. conducted a critical review of the manuscript. All authors have read and agreed to the published version of the manuscript.

Funding: This research received no external funding.

Institutional Review Board Statement: Not applicable.

Informed Consent Statement: Not applicable.

Conflicts of Interest: The authors declare no conflict of interest.

\section{References}

1. Buitrago, M.J.; Martín-Gómez, M.T. Timely Diagnosis of Histoplasmosis in Non-endemic Countries: A Laboratory Challenge. Front. Microbiol. 2020, 11, 467. [CrossRef]

2. Sepúlveda, V.E.; Márquez, R.; Turissini, D.A.; Goldman, W.E.; Matute, D.R. Genome sequences reveal cryptic speciation in the human pathogen Histoplasma capsulatum. mBio 2017, 8, e01339-17. [CrossRef]

3. Mosam, A.; Moodley, V.; Ramdial, P.K.; Sathar, N.; Aboobaker, J.; Singh, S. Persistent pyrexia and plaques: A perplexing puzzle. Lancet 2006, 368, 551. [CrossRef]

4. Oladele, R.O.; Ayanlowo, O.O.; Richardson, M.D.; Denning, D.W. Histoplasmosis in Africa: An emerging or a neglected disease? PLoS Negl. Trop. Dis. 2018, 12, e0006046. [CrossRef]

5. Iams, A.M.; Tenen, M.M.; Flanagan, H.F. Histoplasmosis in children. Review of the literature, report of a case. Am. J. Dis. Child. 1945, 70, 229-240. [CrossRef]

6. Arango, M.; Castañeda, E.; Agudelo, C.I.; De Bedout, C.; Agudelo, C.A.; Tobón, A.; Linares, M.; Valencia, Y.; Restrepo, A.; The Colombian Histoplasmosis Study Group. Histoplasmosis: Results of the Colombian National Survey, 1992-2008. Biomédica 2011, 31, 344-356. [CrossRef] [PubMed]

7. L'opez, L.F.; Valencia, Y.; Tob'on, A.M.; Vel'asquez, O.; Santa, C.D.; C' aceres, D.H. Childhood histoplasmosis in Colombia: Clinical and laboratory observations of 45 patients. Med. Mycol. 2016, 54, 677-683. [CrossRef] [PubMed]

8. Pakasa, N.; Biber, A.; Nsiangana, S.; Imposo, D.; Sumaili, E.; Muhindo, H.; Buitrago, M.J.; Barshack, I.; Schwartz, E. African Histoplasmosis in HIV-Negative Patients, Kimpese, Democratic Republic of the Congo. Emerg. Infect. Dis. 2018, 24, $2068-2070$. [CrossRef] [PubMed]

9. Randhawa, H.S.; Gugnani, H.C. Occurrence of histoplasmosis in the Indian Sub-Continent: An Overview and Update. J. Med. Res. Prac. 2018, 7, 71-83.

10. Schutze, G.E.; Tucker, N.C.; Jacobs, R.F. Histoplasmosis and perinatal human immunodeficiency virus. Pediatr. Infect. Dis. J. 1992, 11, 501-502. [CrossRef] [PubMed]

11. Alverson, B.; Alexander, N.; LeGolvan, M.P.; Dunlap, W.; Levy, C. A human immunodeficiency virus-positive infant with probable congenital histoplasmosis in a nonendemic area. Pediatr. Infect. Dis. J. 2010, 29, 1055-1057. [CrossRef]

12. Whitt, S.P.; Koch, G.A.; Fender, B.; Ratnasamy, N.; Everett, E.D. Histoplasmosis in Pregnancy: Case Series and Report of Transplacental Transmission. Arch. Intern. Med. 2004, 164, 454-458. [CrossRef] [PubMed]

13. Carlucci, J.G.; Halasa, N.; Creech, C.B.; Dulek, D.E.; Gómez-Duarte, O.G.; Nelson, G.E. Vertical Transmission of Histoplasmosis Associated with Anti-Tumor Necrosis Factor Therapy. Pediatr. Infect. Dis. J. 2016, 5, e9-e12. [CrossRef] [PubMed]

14. Zeidberg, L.D.L.; Gass, R.S.; Hutcheson, R.H.; Nashville, T. The Placental Transmission of Histoplasmosis Complement-Fixing Antibodies. Arch. Dis. Child. 1957, 4, 179-184. [CrossRef] 
15. Linder, K.A.; Kauffman, C.A. Histoplasmosis: Epidemiology, Diagnosis and Clinical Manifestations. Curr. Fungal Infect. Rep. 2019, 13, 120-128. [CrossRef]

16. De Pauw, B.; Walsh, T.J.; Donnelly, J.P.; Stevens, D.A.; Edwards, J.E.; Calandra, T.; Pappas, P.G.; Maertens, J.; Lortholary, O.; Kauffman, C.A.; et al. Revised definitions of invasive fungal disease from the European organization for research and treatment of cancer/invasive fungal infections cooperative group and the national institute of allergy and infectious diseases mycoses study group (EORTC/MSG) consensus group. Clin. Infect. Dis. 2008, 46, 1813-1821.

17. Wyborney, V.J.; Walch, H. Histoplasmosis: A Review of Three Cases Studied in San Diego County. Calif. Med. 1966, 105, 265-270. [PubMed]

18. Hirsch, D.; Leupold, W.; Rupprecht, E. Pulmonales Histoplasmom nach Auslandsaufenthalt [Pulmonary histoplasmoma after travel abroad]. Pneumologie 1996, 50, 242-244. [PubMed]

19. Esteves, C.; Costa, F.R.; Macedo, C.; Paiva, D.; Portugal, R.; Madureira, A.J.; Pinto, D.; Guerra, M.C. Histoplasmose Africana. Acta Radiol. Port. 2016, 28, 51-5514.

20. de José Gómeza, M.I.; Hernándeza, M.O.; Garagoitia, A.B.; Rodríguez, J.G.; Artigaoa, F.B. Histoplasmosis diseminada. An. Pediatric 2005, 63, 249-252. [CrossRef]

21. Hess, J.; Fondell, A.; Fustino, N.; Malik, J.; Rokes, C. Presentation and treatment of histoplasmosis in paediatric oncology patients: Case series and review of the literature. Pediatr. Hematol. Oncol. 2017, 39, 137-140. [CrossRef] [PubMed]

22. Hughes, W.T. Hematogenous histoplasmosis in the immunocompromised child. J. Pediatr. 1984, 105, 569-575. [CrossRef]

23. Daubenton, J.D.; Beatty, D.W. Disseminated histoplasmosis in an immunocompetent child. S. Afr. Med. J. 1998, 88, $270-271$.

24. Dhawan, J.; Verma, P.; Sharma, A.; Ramam, M.; Kabra, S.K.; Gupta, S. Disseminated cutaneous histoplasmosis in an immunocompetent child, relapsed with itraconazole, successfully treated with voriconazole. Pediatric Dermatol. 2010, 27, 5. [CrossRef] [PubMed]

25. Kane, J.M.; Schmidt, K.; Conway, J.H. Fever, hepatosplenomegaly and pancytopenia in a five-month-old infant. Arch. Pediatrics Adolesc. Med. 2003, 157, 201-205. [CrossRef]

26. McCllellan, J.T.; Scherr, G.H.; Hotchkiss, M.T. A clinical, pathological, and mycological study of a fatal case of histoplasmosis in an infant. Mycopathol. Mycol. Appl. 1951, 6, 86-91. [CrossRef] [PubMed]

27. Amolsch, A.L.; Wax, J.H. Histoplasmosis in infancy: Report of a case. Am. J. Pathol. 1939, 15, 477-482.

28. Quilter, L.A.S.; Kleiman, M.B.; Kirsch, E.; Wheat, L.J. Disseminated histoplasmosis of infancy in one of the twins. Pediatr. Infect. Dis. J. 2012, 31, 990-991. [CrossRef]

29. Blumberg, R.W.; Ruchmman, I.; Johansmann, R.J. Generalized non-fatal histoplasmosis in an infant. Paediatrics 1949, 3, 296.

30. El-Helou, P.; Rachlis, A.; Fong, I.; Walmsley, S.; Anne, P.; Irving, Jr.S.; Simor, A.E. Mycobacterium xenopi infection in patients with human immunodeficiency virus infection. Clin. Infect. Dis. 1997, 25, 206-210. [CrossRef]

31. Osorio, N.; Lopez, Y.; Jaramillo, J.C. Histoplasmosis of the central nervous system in an immunocompetent patient. Biomedica 2014, 34, 506-513.

32. Ormerod, L.D.; Qamar, T.U.; Toller, K.; Cooperstock, M.S.; Caldwell, C.W.; Giangiacomo, J. Acute Disseminated histoplasmosis with multifocal choroiditis in a child. Paediatr. Infect. Dis. J. 2000, 19, 479-481. [CrossRef]

33. Moriones, R.C.A.; Guerra, O.C.P. Laryngeal histoplasmosis: Report first case in Colombia. Colomb. Med. 2014, 45, 186-189. [CrossRef]

34. Tobon, A.M.; Franco, L.; Espinal, D. Disseminated histoplasmosis in children: The Role of itraconazole therapy. Paediatr. Infect. Dis. J. 1996, 15, 1002-1008. [CrossRef]

35. Lyon, G.M.; Bravo, A.V.; Espino, A.; Lindsley, M.D.; Gutierrez, R.E.; Rodriguez, I.; Corella, A.; Carrillo, F.; McNeil, M.M.; Warnock, D.W.; et al. Histoplasmolsis associated with exploring a bat inhabited cave in Cost Rica, 1998-1999. Am. J. Trop. Med. Hyg. 2004, 70, 438-442. [CrossRef] [PubMed]

36. Odio, C.M.; Navarrete, M.; Carrillo, J.M.; Mora, L.; Carranza, A. Disseminated histoplasmosis in infants. Paediatr. Infect. Dis. J. 1999, 18, 1065-1068. [CrossRef] [PubMed]

37. Pedroza, L.A.; Guerrero, N.; Stray, P.A.; Tafur, C.; Macias, R.; Muñoz, G.; Akdemir, Z.C.; Jhangiani, S.N.; Watkin, L.B.; Chinn, I.K.; et al. First Case of CD40LG Deficiency in Ecuador, Diagnosed after Whole Exome Sequencing in a Patient with Severe Cutaneous Histoplasmosis. Front. Pediatr. 2017, 5, 17. [CrossRef] [PubMed]

38. Garcia-Boyano, M.; Vega, W.; Prieto, L.; Chavez-Solorzano, N.; Montiel, D.S.; Mino-Leon, G. Progressive disseminated histoplasmosis in children living with HIV: A case series study. Eur. J. Pediatr. 2021, 180, 1923-1931. [CrossRef]

39. Vega, W.; Almeida, R.; Minob, G.; Gene, J.; Guarro, J. A quick and cost-effective method for diagnosing disseminated histoplasmosis in children. Diagn. Microbiol. Infect. Dis. 2007, 57, 405-440. [CrossRef]

40. Nicholson, A.M.; Rainford, L.; Elliot, V.; Christie, C.D. Disseminated histoplasmosis and AIDS at the university hospital of the West Indies. A case report. West. Indian Med. J. 2004, 53, 126-130.

41. Jimenez, E.; Navarrete, M.; Mohs, E.; Carrillo, J.M.; Lizano, C. Disseminated histoplasmosis in children. Boletín Médico Hospital Infantil México 1980, 37, 927-934.

42. Nandi-Lozano, E.; Newton-Sanchez, O.; Avila-Figueroa, C. Systemic histoplasmosis. Report of 5 paediatric cases. Boletin Medico Hospital Infantil Mexico 2006, 63, 47-54.

43. Ramon-Garcia, G.; Pena-Alonso, Y.R.; Ontiveros-Nevares, P.G. Disseminated histoplasmosis in children. Bol. Med. Hosp. Infant Mex. 1993, 50, 870-875. [PubMed] 
44. Muñoz, B.; Martínez, M.A.; Palma, G.; Ramírez, A.; Frías, M.G.; Reyes, M.R.; Taylor, M.L.; Higuera, A.L.; Corcho, A.; Manjarrez, M.E. Molecular characterization of Histoplasma capsulatum isolated from an outbreak in treasure hunters Histoplasma capsulatum in treasure hunters. BMC Infect. Dis. 2010, 10, 264. [CrossRef]

45. Saidinejad, M.; Burns, M.M.; Harper, M.B. Disseminated histoplasmosis in a non-endemic area. Paediatr. Infect. Dis. J. 2004, 23, 781-782. [CrossRef] [PubMed]

46. Evans, H.E.; Campbell, C.C.; Utz, J.P. Infantile disseminated histoplasmosis: A case reporting pillow feathers as a source of infections. JAMA 1962, 15, 999-1000. [CrossRef]

47. Goodwin, R.A.; Nickell, J.A.; Des Prez, R.M. Mediastinal fibrosis complicating healed primary histoplasmosis and tuberculosis. Medicine 1972, 51, 227-246. [CrossRef]

48. Brodeur, G.M.; Wilber, R.B.; Melvin, S.L.; Murphy, S.B. Histoplasmosis mimicking childhood non-Hodgkin lymphoma. Med. Pediatr. Oncol. 1979, 7, 77-81. [CrossRef]

49. Dotson, J.L.; Crandall, W.; Mousa, H.; Honegger, J.R.; Denson, L.; Samson, C.; Cunningham, D.; Balint, J.; Dienhart, M.; Jaggi, P.; et al. Presentation and outcome of histoplasmosis in pediatric inflammatory bowel disease patients treated with antitumor necrosis factor alpha therapy: A case series. Inflamm. Bowel Dis. 2011, 17, 56-61. [CrossRef]

50. Celebi, N.; Vallejo, J.G.; Eckstein, O.S.; Geer, J.; Punia, J.N.; Elenberg, E. Persistent fever in a paediatric renal transplant patient: Answers. Pediatr. Nephrol. 2019, 34, 825-828. [CrossRef] [PubMed]

51. Gudala, M.; Hegde, S. Delayed diagnosis of pulmonary histoplasmosis in an immunocompetent young asthmatic female from Florida, a non-endemic area for Histoplasma capsulatum. Med. Mycol. 2015, 1, 1-6. [CrossRef]

52. Johansen, M.; Hoyer, M.; Kleiman, M. Transcatheter treatment of SVC syndrome from histoplasmosis-related mediastinal fibrosis in a 9-Year-old male. Catheter. Cardiovasc. Interv. 2013, 82, E708-E711. [CrossRef] [PubMed]

53. Wheat, L.J.; Wass, J.; Norton, J.; Kohler, R.B.; Morris, L.V. Cavitatory histoplasmosis occurring during two large urban outbreaks. Analysis of clinical, epidemiologic, roentgenographic and laboratory features. Medicine 1984, 6, 201-209. [CrossRef]

54. Tesh, R.B.; Shacklette, M.H.; Diercks, F.H.; Hirschl, D. Histoplasmosis in children. Paediatrics 1964, 33, 894-903.

55. Cox, F.; Hughes, W.T. Disseminated histoplasmosis and childhood Leukemia. Cancer 1974, 33, 1127-1133. [CrossRef]

56. Pate, J.W.; Hammon, J. Superior vena cava syndrome due to histoplasmosis in children. Ann. Surg. 1965, 161, 778-787. [CrossRef] [PubMed]

57. Quellete, C.P.; Stanek, J.R.; Leber, A.; Ardura, M.I. Paediatric histoplasmosis in an area of endemicity: A contemporary analysis. J. Paediatr. Inf. Dis. Soc. 2019, 8, 400-407.

58. Kimm, E.E.; DeLand, F.H. V/Q mismatch without pulmonary emboli in children with histoplasmosis. Clin. Nucl. Med. 1978, 3 , 328-330. [CrossRef]

59. Woods, W.G.; Nesbit, M.E. Histoplasmosis simulating lymphoma in children. J. Paediatr. Surg. 1979, 14, 423-425. [CrossRef]

60. Chin, T.D.Y.; Ney, P.E.; Saltzman, B.N.; Paxton, G.B.; Rakich, J.H.; Ware, M.; Whitmore, M.; Furcolow, M.L. An epidemic of histoplasmosis among school children in Arkansas. South. Med. J. 1956, 49, 785-792. [CrossRef]

61. Adderson, E.E. Histoplasmosis in a Paediatric oncology centre. J. Paediatr. 2004, 144, 100-106. [CrossRef]

62. Butler, J.; Heller, R.; Wright, P. Histoplasmosis during childhood. South. Med. J. 1994, 87, 476-480. [CrossRef] [PubMed]

63. Klinberg, W.G. Generalized histoplasmosis in infants and children: Review of ten cases, one with apparent recovery. J. Paediatr. 1950, 36 .

64. Soper, R.T.; Silber, D.L.; Holcomb, G.W. Gastrointestinal histoplasmosis in children. J. Paediatr. Surg. 1970, 5, 32-39. [CrossRef]

65. Pryor, H.B. Histoplasmosis in California children. J. Paediatr. 1949, 34, 12-19. [CrossRef]

66. Fojtasek, M.; Kleiman, M.; Connolly-Stringfield, P.; Blair, R.; Wheat, L.J. The Histoplasma capsulatum antigen assay in disseminated histoplasmosis in children. Paediatr. Infect. Dis. J. 1994, 13, 801-805. [CrossRef]

67. Leggiadro, R.J. Disseminated histoplasmosis in persons with interferon-gamma receptor 1 deficiency. Paediatr. Infect. Dis. J. 2006, $25,98$.

68. Gaebler, J.W.; Kleiman, M.B.; Cohen, M.; French, M.L.V.; Grosfeld, J.L.; Weber, T.R.; Weetman, R. Differentiation of lymphoma from histoplasmosis in children with mediastinal masses. J. Paediatr. 1984, 104, 706-709. [CrossRef]

69. Weinberg, G.A.; Kleiman, M.B.; Grosfeld, J.L.; Weber, T.R.; Wheat, L.J. Unusual manifestations of histoplasmosis in childhood. Paediatrics 1983, 72, 99-105.

70. Gaissert, H.A.; Grillo, H.C.; Mathisen, D.J.; Wain, J.C. Resection and reconstruction of the carina in children and adolescents. Langenbecks Arch. Chir. 1995, 380, 166-170.

71. Sonawalla, A.; Tas, V.; Raisingani, M.; Tas, E. A rare and potentially fatal aetiology of hypercalcemia in an Infant. Case Rep. Endocrinol. 2019. [CrossRef] [PubMed]

72. Kalata, K.E.; Osborne, C.; Willis, A.; Navarro, K.; Fenton, L.Z.; Smith, C. Disseminated histoplasmosis as an AIDS-defining illness presenting as fever of unknown origin in an 11-Year-old female. Case Rep. Pediatrics 2019. [CrossRef]

73. Robinson, W.S.; Arnold, S.R.; Michael, C.F.; Vickery, J.D.; Schoumacher, R.A.; Pivnick, E.K.; Ward, J.C.; Nagabhushanam, V.; Lew, D.B. Case report of a young child with disseminated histoplasmosis and review of hyper immunoglobulin E syndrome (HIES). Clin. Mol. Allergy 2011, 9, 14. [CrossRef]

74. Kirchner, S.G.; Hernanz-Schulman, M.; Stein, S.M.; Wright, P.F.; Heller, R.M. Imaging of paediatric mediastinal histoplasmosis. RadioGraphics 1991, 11, 3. [CrossRef] 
75. McGraw, E.P.; Kane, J.M.; Kleiman, M.B.; Schere, L.R. Cervical abscess and mediastinal adenopathy: An unusual presentation of childhood histoplasmosis. Pediatr. Radiol. 2002, 32, 862-864. [CrossRef]

76. Walter, J.F.; Sodeman, T.M.; Cooperstock, M.S.; Bookstein, J.J.; Whitehouse, W.M. Lymphangiographic findings in histoplasmosis. Diagn. Radiol. 1975, 114, 65-66. [CrossRef]

77. Zahn, M.; Hesson, M.; Morton, R.; Wheat, L.J. Granulomatous pleuritis caused by histoplasmosis in a healthy child. Pediatr. Pulmonol. 2011, 46, 729-731. [CrossRef]

78. Tschudy, J.; Michail, S. Disseminated histoplasmosis and pneumocystis pneumonia in a child with Crohns disease receiving infliximab. JPGN 2010, 51. [CrossRef] [PubMed]

79. Rivera, I.V.; Curless, R.G.; Indacochea, F.J.; Scott, G.B. Chronic progressive CNS histoplasmosis presenting in childhood: Response to fluconazole therapy. Pediatr. Neurol. 1992, 8, 151-153. [CrossRef]

80. Bergstein, J.M.; Kleiman, M.; Ballantine, T.V.N. Long-term outpatient amphotericin B therapy via a silicone central alimentation catheter. J. Pediatr. Surg. 1983, 18. [CrossRef]

81. Landay, M.J.; Rollins, N.K. Mediastinal histoplasmosis granuloma. Radiology 1989, 172, 657-659. [CrossRef]

82. Steiner, S.J.; Kleiman, M.B.; Corkins, M.R.; Christenson, J.C.; Wheat, L.J. Ileocecal histoplasmosis simulating Crohns disease in a patient with hyperimmunoglobulin E syndrome. Pediatr. Infect. Dis. J. 2009, 28, 744-746. [CrossRef] [PubMed]

83. Sieving, R.R.; kaufmann, C.A.; Watanakunakom, C. Deep fungal infection in systemic lupus erythematosus-three cases reported, literature reviewed. J. Rheumatol. 1975, 2, 61-72. [PubMed]

84. Threlkeld, Z.D.; Broughton, R.; Khan, G.Q.; Berger, J.R. Isolated Histoplasma capsulatum meningoencephalitis in an immunocompetent child. J. Child. Neurol. 2012, 27, 532-535. [CrossRef]

85. Wieder, S.; Rabinowitz, J.G. Fibrous mediastinitis: A late manifestation of mediastinal histoplasmosis. Radiology 1977, 125, 305-312. [CrossRef]

86. Abul, M.H.; Tuano, K.; Healy, C.M.; Vece, T.J.; Quintanilla, N.M.; Davis, C.M.; Seeborg, F.O.; Hanson, I.C. A 15-year-old boy with severe combined immunodeficiency, fungal infection, and weight gain. Allergy Asthma Proc. 2015, 36, 407-411. [CrossRef] [PubMed]

87. Schuster, J.E.; Wushensky, C.A.; Di Pentima, M.C. Chronic primary central nervous system histoplasmosis in a healthy child with intermittent neurological manifestations. Pediatr. Infect. Dis. J. 2013, 32. [CrossRef]

88. Tutor, J.D.; Schoumacher, R.A.; Chesney, P.J. Chylothorax associated with histoplasmosis in a child. Pediatr Infect. Dis J. 2000, 19, 262-263. [CrossRef]

89. Odio, C.D.; Ki Lee Milligan, B.A.; McGowan, K.; Spergel, A.K.R.; Bishop, R.; Boris, L.; Urban, A.; Welch, P.; Heller, T.; Kleiner, D.; et al. Endemic mycoses in patients with STAT3 mutated hyperimmunoglobulin E (Job's) syndrome. Clin. Immunol. 2015, 136, 1411-1413.e2.

90. Haselow, D.T.; Safi, H.; Holcomb, D.; Smith, N.; Wagner, K.D.; Bolden, B.B.; Harik, N.S. Histoplasmosis associated with a bamboo bonfire-Arkansas. Morb. Mortal. Wkly. Rep. MMWR 2014, 63, 165-168.

91. Keller, F.G.; Kurtzberg, J. Disseminated histoplasmosis: A cause of infection-associated hemophagocytic syndrome. Am. J. Pediatr. Hematol. Oncol. 1994, 16, 368-371. [PubMed]

92. Lo, M.M.; Mo, J.Q.; Dixon, B.P.; Czech, K.A. Disseminated histoplasmosis associated with hemophagocytic lymphohistiocytosis in kidney transplant recipients. Am. J. Transplant. 2010, 10, 687-691. [CrossRef] [PubMed]

93. Steiner, S.J.; Cox, E.G.; Gupta, S.K.; Kleiman, M.B.; Fitzgerald, J.F. Esophageal diverticulum: A complication of histoplasmosis in children. Clin. Lab. 2005, 146, 26-428. [CrossRef]

94. Ferguson-Paul, k.; Park, C.; Childress, S.; Arnold, S.; Ault, B.; Bagga, B. Disseminated histoplasmosis in pediatric kidney transplant recipients-A report of six cases and review of the literature. Pediatr. Transplant. 2018, 22, e13274. [CrossRef] [PubMed]

95. Scott, B.L.; Sherwin, J.I.; Rehder, K.J.; Campbell, M.J.; Ozment, C.P. Histoplasmosis myocarditis in an immunocompetent host after a recreational mud run. Pediatrics 2018, 141, S462-S465. [CrossRef] [PubMed]

96. Zeanah, C.H.; Zusman, J. Mediastinal and cervical histoplasmosis simulating malignancy. Am. J. Dis Child. 1979, 133, 47-49. [CrossRef]

97. Collins, M.; Jiang, B.; Croffie, J.; Chong, S.; Lee, C. Hepatic granulomas in children: A clinicopathologic analysis of 23 cases including polymerase chain reaction for Histoplasma. Am. J. Surg. Pathol. 1996, 20, 332-338. [CrossRef]

98. Naeem, F.; Metzger, M.L.; Arnold, S.R.; Adderson, E.E. Distinguishing benign mediastinal masses from malignancy in a histoplasmosis-endemic region. J. Pediatr. 2015, 167, 409-415. [CrossRef] [PubMed]

99. Little, J.A. Benign primary pulmonary histoplasmosis: A common cause of unexplained fever in children. South. Med. J. 1960, 53, 1238-1240. [CrossRef]

100. Weijie, Li.; Sharma, M. Unusual cause of infant pancytopenia: Granulomatous bone marrow lesion with disseminated histoplasmosis. Blood 2018, 131, 1154.

101. Kirchner, S.G.; Heller, R.M.; Sell, S.H.; Altemeier, W.A. The radiological features of histoplasma pericarditis. Pediat. Radiol. 1978, 7, 7-9. [CrossRef]

102. Hunstad, D.A.; French, A.R. Histoplasmosis in a child with JRA on low-dose methotrexate. Rheumatology 2007, 46, 177-178. [CrossRef]

103. Kakos, G.S.; Kilman, J.W. Symptomatic histoplasmosis in children. Ann. Thoracic. Surg. 1973, 15, 622-627. [CrossRef] 
104. Johnson, J.A.; Loyd, J.E.; Wheat, L.J.; Netterville, J.L. A case series and review of histoplasmosis infection in the neck. Arch. Otolaryngol Head Neck Surg. 2010, 136, 916. [CrossRef]

105. Iams, A.M.; Keith, H.M. Histoplasmosis in infancy, with a brief clinicopathologic review. J. Paediatr. 1947, 30, 123-128. [CrossRef]

106. Bennish, M.; Radkowski, M.A.; Ripon, J.W. Cavitation in acute histoplasmosis. Chest 1983, 84, 496-497. [CrossRef] [PubMed]

107. Lee, T.; Woods, C.; O'Hagan, A. Broncholithiasis from histoplasmosis in a paediatric patient: Case report and review of literature. J. Pediat. Inf. Dis. Soc. 2013, 2, 76-79. [CrossRef]

108. Rosenthal, J.; Brandt, K.D.; Wheat, L.J.; Slama, T.G. Rheumatologic manifestations of histoplasmosis in the recent Indianapolis epidemic. Arthritis Rheum. 1983, 26, 1065-1070. [CrossRef]

109. Raftery, L.A. Subclinical histoplasmosis (gastrointestinal histoplasmosis of children). JAMA 1951, 145, 216-219. [CrossRef] [PubMed]

110. Staszak, J.K.; Zmijewski, P.; Arnold, S.; Bagga, B.; Williams, R.F. Mediastinal lymphadenopathy in Children with histoplasmosis. J. Surg. Res. 2019, 244, 558-565. [CrossRef]

111. Zerbe, C.S.; Holland, S.M. Disseminated histoplasmosis in persons with interferon-g receptor 1 deficiency. Clin. Infect. Dis. 2005, 41, e38-e41. [CrossRef] [PubMed]

112. Beckerman, R.C. Birds in the attic, bats in the belfry: A closet case. South. Med. J. 1994, 87, 961-962. [CrossRef]

113. Wheat, L.J.; Slama, T.G.; Eitzen, H.E.; Kohler, R.B.; French, M.L.L.V.; Biesecker, J.L. A large urban outbreak of histoplasmosis: Clinical features. Ann. Int. Med. 1981, 94, 331-337. [CrossRef]

114. Weber, T.R.; Grosfeld, J.L.; Kleiman, M.B.; Cohen, M.; Greenman, G. Surgical implications of endemic histoplasmosis in children. J. Pediatr. Surg. 1983, 18, 486-491. [CrossRef]

115. Kneidel, J.H.; Segall, A.H. Acute disseminated histoplasmosis in children. Report of three cases. Paediatrics $1949,4,596$.

116. Di Pentima, M.C. Recurrent post sternotomy mediastinitis due to histoplasmosis: The critical role of histopathology in surgical site infections. Ann. Pediatr. Surg. 2016, 12, 22-24. [CrossRef]

117. Voto, C.; Pérez, M.G.; Gómez, S.; Epelbaum, C.; Sarkis, C.; Santos, P.; Carnovale, S.; Canteros, C.; Bologna, R. Histoplasmosis in Argentina: Case series in children. Rev. Iberoam. Micol. 2020, 37, 34-36. [CrossRef]

118. Estebana, I.; Mincesb, P.; De Cristofanoc, A.M.; Negronid, R. Central nervous system histoplasmosis in an immunocompetent pediatric patient. Arch. Argent. Pediatr. 2016, 114, e171-e174.

119. de Komaid, A.G.; Duran, E.; Borges de Kestelman, I. Histoplasmosis and Paracoccidioidomycosis in northwestern Argentina III. Epidemiological survey in Vipos, La Toma, and Choromoro \pm Trancas, TucumaÂ n, Argentina. Eur. J. Epidemiol. 1999, 15, 381-386. [CrossRef] [PubMed]

120. Lima da Silva, C.G.; Vieira, R.M.; Simões-Neto, E.A.; Pereira Lopes, J.M.; Rodrigues, R.B.; Faé, B.N.; Junior, J.G.; Neto, M.L.; dos Santos, M.D. Disseminated histoplasmosis in the child with diabetes mellitus: Case Report. J. Pharm. Biomed. Sci. 2014, 4, 1153-1159.

121. Fischer, G.B.; Mocelin, H.; Severo, C.B.; Oliveira, F.; Xavierc, M.O.; Severo, L.C. Histoplasmosis in children. Paediatr. Respir. Rev. 2009, 10, 172-177. [CrossRef]

122. França, C.M.P.; Cavalcante, E.G.; Ribeiro, A.S.M.; Oliveira, G.T.; Litvinov, N.; Silva, C.A. Disseminated histoplasmosis in a juvenile lupus erythematosus patient. Acta Reumatol. Port. 2012, 37, 276-279.

123. Cimerman, S.; Sokolowski, W.; Gonçalves, S.E.; Lins, M.S.; Colombo, A.L. Case report. Histoplasmosis in an AIDS paediatric patient. Mycoses 1999, 42, 567-569. [CrossRef]

124. Levi, G.C.; Pozzi, C.M.; Hirschheimer, S.M.D.S.; Chahade, W.H.; Gomes, H.R.; Granato, C. Central nervous system involvement by histoplasmosis as the unique manifestation of this disease in immunocompetent patients: Presentation of two cases. Arq Neuropsiquiatr. 2003, 61, 859-886. [CrossRef] [PubMed]

125. de Souza, L.T.; de Souza, C.F.R.C.; Azevedo da Silva, J.; Alves, J.V.G.; Coelho, A.G.; Souza, F.A.C.; Moreira Salomão Simão, N.M.; Souto Filho, J.T.; Deswarte, C.; Boisson-Dupuis, S.; et al. Microbial disease spectrum linked to a Novel IL-12R $\beta 1$ N-terminal signal peptide stop-gain homozygous mutation with paradoxical receptor cell-surface expression. Front. Microbiol. $2017,8,616$.

126. Peçanha, M.A.C.; Neves, C.M.L.; Lopes, A.A.; Querino, S.N.N.; Araújo, N.N.; Matos, P.K. Histoplasmosis presenting as acute respiratory distress syndrome after exposure to bat faeces in a home basement. Braz. J. Infect. Dis. 2000, 4, $103-106$.

127. Pereira, G.H.; Pádua, S.S.; Park, M.V.F.; Muller, R.P.; Passos, R.M.A.; Menezes, Y. Chronic meningitis by histoplasmosis: Report of a child with acute myeloid leukemia. Braz. J. Infect. Dis. 2008, 12, 555-557. [CrossRef]

128. Schestatsky, P.; Chedid, M.F.; Amaral, O.B.; Unis, G.; Oliveira, F.M.; Severo, L.C. Isolated central nervous system histoplasmosis in immunocompetent hosts: A series of 11 cases. Scand. J. Infect. Dis. 2006, 38, 43-48. [CrossRef]

129. Coiffier, T.; Garabedian, E.N.; Roger, G.; Beust, L.; Quinet, B.; Adam, D.; Dupont, B.; Garabedian, E.N. Pharyngeal-laryngeal histoplasmosis: One case in an immunocompetent child. Int. J. Paediatr. Otorhinolaryngol. 1998, 45, 177-181. [CrossRef]

130. Mata-Essayag, S.; Colella, M.T.; Rosello', A.; Hartung de Capriles, C.; Landaeta, M.E.; Pe' rez de Salazar, C.; Magaldi, S.; Olaizola, C.; Calatroni, M.I.; Garrido, L. Histoplasmosis: A Study of 158 Cases in Venezuela, 2000-2005. Medicine 2008, 87, 193-202. [CrossRef] [PubMed]

131. Delclaux, C.; Schutz, R. Generalized histoplasmosis due to Histoplasma duboisii with mediastino-pulmonary infection. Cure after 15 months of treatment with Ketoconazole. Rev. Mal. Respir. 1992, 9, 559-560. [PubMed]

132. Picq, J.J.; Ricosse, J.H.; Albert, J.P.; Drouhet, E. 2 cases of African histoplasmosis in Upper Volta. Med. Trop. 1968, $28,67-74$.

133. André, C.; Badoual, J.; Kalifa, G.; Dubousset, J. [African histoplasmosis. A case]. Arch. Fr. Pediatr. 1984, 41, 429-431. 
134. Lesbordes, J.L.; Beuzit, Y. A case of histoplasmosis caused by Histoplasma duboisii and treated by ketoconazole in Bangui (C.A.R). Med. Trop. (Mars.) 1986, 46, 303-305.

135. Garcia-Guiñon, A.; Torres-Rodríguez, J.M.; Ndidongarte, D.T.; Cortadellas, F.; Labrín, L. Disseminated histoplasmosis by Histoplasma capsulatum var. duboisii in a paediatric patient from the Chad Republic, Africa. Eur. J. Clin. Microbiol. Infect. Dis. 2009, 28, 697-699. [CrossRef]

136. Chandenier, J.; Goma, D.; Moyen, G.; Samba-Lefebvre, M.C.; Nzingoula, S.; Nkiwabonga, L.; Ngaporo, A.I. African histoplasmosis due to Histoplasmosis capsulatum var. duboisii: Relationship with AIDS in recent Congolese cases. Sante 1995, 5, $227-234$.

137. Mabiala, J.R.; Mandavo, C.M.; Evrard, R.N.; Ibara, B.O.; Lamah, L.; Mouko, A.; Peko, J.F. Trois cas pédiatriques d’histoplasmose africaine à Brazzaville. J. Mycol. Méd. 2017, 27, 133-138. [CrossRef]

138. Destombes, P.; Ravisse, P.; Nazimoff, O. Assessment of deep mycoses established in twenty years of histopathology at the Pasteur Institute of Brazzaville. Bull. Soc. Pathol. Exot. 1970, 63, 315-323.

139. Carme, B.; Hayette, M.; Ngaporo, A.I.; Ngolet, A.; Darozzin, F.; Moyikoua, A. African histoplasmosis due to Histoplasma duboisii (Histoplasma capsulatum var. duboisii): Fourteen Congolese cases observed in 10 years (1981-1990). J. Mycol. Med. 1993, 1991, 67-73.

140. Griffet, P.; Poaty-Mapakou, C.; Bouyou-Mananga, E.; Samson, P. African histoplasmosis due to Histoplasma duboisii: Report of an exemplary case with cutaneous and bone localization. Med. Armee 1984, 12, 679.

141. Moyikoua, A.; Carme, B.; Ngolet, A.; Pena-Pitra, B. African histoplasmosis: Report of a case of osteoarthritis of the shoulder. Med. Afr. Noire 1991, 3S, 372-376.

142. Okoko, A.; Bowassa, G.E.; Oko, A. Generalized histoplasmosis in a child immunocompetent to HIV. Med. Afr. Noire 2010, 57, 590-592.

143. Eboulabeka, G.K.; Ngolet, A. Fronto-orbital-palpebral swelling indicative of African histoplasmosis caused by Histoplasma capsulatum var duboisii in a 13-month-old infant. About a clinical observation and review of the literature. Med. Afr. Noire 2011, 58, 144-148.

144. Paugam, A.; de Pe coulas, P.E.; Boure 'e, P. African young girl with sores of the elbow, cold abcesses and molluscum-like cutaneous lesions. Lett. Infect. 2014, 7, 126-129.

145. N'Golet, A.; N'Gouoni, B.G.; Moukassa, D.; Nkoua-Mbon, J.B. Maxillary African histoplasmosis: Unusual diagnostic problems of an unusual presentation. Pathol. Res. Pract. 2005, 200, 841-844. [CrossRef] [PubMed]

146. Ahogo, K.C.; Sangare, A.; Gbery, I.P.; Ecra, E.; Kaloga, M.; Kassi, K.; Kouamé, K.; Kourouma, A.K.; Abadjinan, A.; Kacou, D.E.; et al. Cutaneous histoplasmosis due to Histoplasma capsulatum variety duboissi in an immune competent child. About one case in Abidjan, Cote d'voire. Bull. Soc. Pathol. Exot. 2009, 102, 147-149.

147. Sangare, A.; Yoboue, P.; Ahogo, C.; Ecra, E.; Kaloga, M.; Gbery, I.; Kanga, J.M. Disseminated cutaneous histoplasmosis due to Histoplasma capsulatum var. duboissi associated with AIDS. A case report in Abidjan, Cote d'voire. Bull. Soc. Exot. 2008, 101, 5-7.

148. Bankolé, S.R.; Denoulet, C.; Coulibaly, B.; Nandiolo, R.; Kassi, E.; Honde, M.; Mobiot, M.L. A propos d'un cas ivoirien d'histoplasmose osseuse et cutanée à Histoplasma capsulatum var. duboisii [Apropos of 1 Ivoirian case of osseus and cutaneous histoplasmosis by Histoplasma capsulatum var. duboisii]. Bull. Soc. Pathol. Exot. 1998, 91, 151-153.

149. Mabey, D.C.W.; Hay, R.J. Further studies on the treatment of African histoplasmosis with ketoconazole. Trans. R. Soc. Trop. Med. Hyg. 1989, 83, 560-562. [CrossRef]

150. Gonçalves, D.; Ferraz, C.; Vaz, L. Posaconazole as rescue therapy in African histoplasmosis. Braz. J. Infect. Dis. 2013, 17, 102-105. [CrossRef]

151. Pamnani, R.; Rajab, J.; Githang'a, J.; Kasmani, R. Disseminated histoplasmosis diagnosed on bone marrow aspirate cytology: Report of four cases. East. Afr. Med. J. Kenya Med. Assoc. 2010, 86, 102-105. [CrossRef]

152. Minta, D.K.; Sylla, M.; Traore, A.M.; Soukho-Kaya, A.; Coulibaly, I.; Diallo, K.; Thera, M.A.; Sidibé, A.T.; Sidibé, S.; Traoré, H.A.; et al. Première observation malienne d'histoplasmose africaine disséminée à predominance osseuse chez un enfant VIH négatif. Revue de la iterature. J. Mycol. Méd. 2013, 423, 6.

153. Ubesie, A.C.; Okafo, O.C.; Ibeziako, N.S.; Onukwuli, V.O.; Mbanefo, N.R.; Uzoigwe, J.C.; Bede, C.; Ibe, B.C. Disseminated Histoplasmosis in a 13-year-old girl: A case report. Afr. Health Sci. 2013, 13, 518-521. [CrossRef] [PubMed]

154. Seriki, O.; Aderele, W.I.; Johnson, A.; Smith, J.A. Disseminated histoplasmosis due to Histoplasma capsulatum in two Nigerian children. J. Trop. Med. Hyg. 1975, 78, 248-255. [PubMed]

155. Katchy, A.U.; Eyesan, S.U.; Awotunde, T.O.; Adesina, S.A.; Ayandele, B.O.; Sabageh, D. Histoplasma duboisii of the femoral bone. J. Res. Med. Sci. 2019, 24, 19. [PubMed]

156. Mace, M.C. Oral African histoplasmosis resembling Burkitt's lymphoma. Oral Surg. 1978, 46, 407-412. [CrossRef]

157. Khalil, M.A.; Hassan, A.W.; Gugnani, H.C. African histoplasmosis: Report of four cases from north-eastern Nigeria. Mycoses 1997, 41, 293-295. [CrossRef]

158. Ige, A.O.; Nwosu, S.O.; Odesanmi, W.O. African histoplasmosis (Duboisii) of the skull with neurological complication-a case report and review of literature. Afr. J. Med. Med. Sci. 1992, 21, 19-21. [PubMed]

159. Ajayi, B.G.; Osuntokun, B.; Olurin, O.; Kale, O.O.; Junaid, T.A. Orbital histoplasmosis due to Histoplasma capsulatum var. duboisii: Successful treatment with Septrin. J. Trop. Med. Hyg. 1986, 89, 179-187. [PubMed] 
160. Onwuasoigwe, O. Fluconnazole in the therapy of multiple osteomyelitis in African histoplasmosis. Int. Orthopaedics 1999, 23, 82-84. [CrossRef] [PubMed]

161. Akpuaka, F.C.; Gugnani, H.C.; Iregbulam. African histoplasmosis: Report of two patients treated with amphotericin B and ketoconazole. Mycoses 1998, 41, 363-364. [CrossRef] [PubMed]

162. Pillay, T.; Pillay, D.G.; Bramdev, A. Disseminated histoplasmosis in a human immunodeficiency virus infected African child. Paediatr. Infect. Dis. J. 1997, 16, 417-418. [CrossRef]

163. Mackenjee, M.K.; Coovadia, H.M. Histoplasmosis treated with a sulphonamide. A case report. S. Afr. Med. J. 1976, 20, $2015-2016$.

164. Kabangila, R.; Semvua, K.; Rambau, P.; Jackson, K.; Mshana, S.E.; Jaka, H.; Peck, R.N. Pulmonary histoplasmosis presenting as chronic productive cough, fever, and massive unilateral consolidation in a 15-year-old immune-competent boy: A case report. J. Med. Case Rep. 2011, 5, 374. [CrossRef]

165. Suleman, F.E.; Scheepers, P.A. Multiple skeletal lesions and pleural effusion owing to Histoplasma capsulatum infection in an immunocompetent patient from a nonendemic region. S. Afr. J. Radiol. 2011, 15, 3. [CrossRef]

166. Crump, J.A.; Ramadhani, H.O.; Morrissey, A.B.; Msuya, L.J.; Yang, L.-Y.; Chow, S-C.; Morpeth, S.C.; Reyburn, H.; Njau, B.N Invasive bacterial and fungal infections among hospitalized HIV-infected and HIV-uninfected children and infants in northern Tanzania. Trop. Med. Int. Health 2011, 16, 830-837. [CrossRef]

167. Pitche, P.; Dossim, A.; Mijiyawa, M.; Napo-Koura, G.; Tchangaï-Walla, K. Atteinte multi-osseuse au cours d'une forme disséminée $\mathrm{d}$ 'histoplasmose africaine chez un enfant togolais immuno-compétent [Multiple bone lesions of a type of disseminated African histoplasmosis in a Togolese. Rev. Chir. Orthop. Reparatrice Appar. Mot. 1995, 81, 745-748.

168. Kweyamba, V.; Apiyo, M.; Olika, B.; Kituuka, O. A Case of a 4-Year-Old Boy with a Mesenteric Chylous Cyst Infected with Histoplasma capsulatum. Case Rep. Surg. 2016, 3-7. [CrossRef]

169. Lamey, B.; Parisien, G. Disseminated form of histoplasmosis caused by Histoplasma capsulatum in a Zairian child. Med. Trop. 1982, 42, 557-559.

170. Zhou, L.; Fan, S.; Liang, Q.; Peng, Y.; Zong, D.; Ouyang, R. Clinical characteristics of histoplamosis in 8 patients: Case report and literature review. Journal of Central South University. Med. Sci. 2016, 41, 644-652. [CrossRef]

171. Chen, Y.X.; Li, W.Z. Histoplasmosis complicated by Mycobacterial infections in one child. Zhongguo Dang Dal Er Ke Za Zhi. 2008, $10,92-93$.

172. Lu Huang, Y.; Wu, X.M. Localized Histoplasma capsulatum osteomyelitis of the fibula in an immunocompetent teenage boy: A case report. BMC Infect. Dis. 2013, 13, 1-15. [CrossRef]

173. Boucher, J.D.; Black, M.L. Out of town guest: A healthy 7-year-old from a non-endemic area presents with histoplasmosis granulomatous disease. ID Cases 2018, 12, 121-123. [CrossRef] [PubMed]

174. Ecka, R.S.; Bhatia, P.; Varma, N.; Marwaha, R.K. Disseminated histoplasmosis with Peripheral Blood Spill Over. Indian J. Pediatr. 2013. [CrossRef] [PubMed]

175. Agarwal, P.; Capoor, M.R.; Singh, M.; Gupta, A.; Chhakchhuak, A.; Debatta, P. An unusual presentation of disseminated histoplasmosis: Case report and review of paediatric immunocompetent patients from India. Mycopathologia 2015, 180, 359-364. [CrossRef]

176. Mathews, D.M.; John, R.; Verghese, V.; Parmar, H.; Chaudhary, N.; Mishra, S.; Mathew, L. Histoplasma capsulatum infection with extensive lytic bone lesions mimicking LCH. J. Trop. Pediatr. 2016, 62, 496-499.

177. Gupta, A.; Ghosh, A.; Singh, G.; Xess, I. A twenty-first-century perspective of disseminated histoplasmosis in India: Literature review and retrospective analysis of published and unpublished cases at a tertiary care hospital in north India. Mycopathologia 2017, 182, 1077-1093. [CrossRef]

178. Hevroni, A.; Springer, C.; Wasser, O.; Avital, A.; Koplewitz, B.Z. Recurrent pneumonia due to fibrosing mediastinitis in a teenage girl: A case report with Long-Term Follow-Up. Case Rep. Pediatr. 2018, 2018, 3246929. [CrossRef]

179. Hasliza, M.; Nur, A.N.A.; Lim, C.B.; Hussain, I.H.M.I. Disseminated Histoplasmosis in a Non-Immunocompromised Child. Med. J. Malays. 1999, 54, 120-124.

180. Ponnampalam, J.T. Histoplasmosis in Malaya. Br. J. Dis. Chest. 1964, 58, 49. [CrossRef]

181. Qureshi, A. A case of Histoplasmosis mimicking tuberculosis. J. Pak. Med. Assoc. 2008, 58, 457. [PubMed]

182. Wisanuyotin, S.; Jiravuttipong, A.; Siritunyaporn, S. Disseminated histoplasmosis in a renal transplant child. Southeast. Asian J. Trop. Med. Public Health 2012, 43, 992-996. [PubMed]

183. Yilmaz, G.G.; Yilmaz, E.; Coşkun, M.; Karpuzoğlu, G.; Gelen, T.; Yeğin, O. Cutaneous histoplasmosis in a child with hyper-IgM. Pediatr. Dermatol. 1995, 12, 235-238. [CrossRef] [PubMed]

184. World Health Organisation. Children: Improving Survival and Wellbeing. 2020. Available online: https://www.who.int/newsroom/fact-sheets/detail/children-reducing-mortality (accessed on 17 March 2021).

185. Katona, P.; Katona-Apte, J. The interaction between nutrition and infection. Clin. Infect. Dis. 2008, 46, 1582-1588. [CrossRef]

186. Russ, A.; Rjoop, A.; Levy, R.A.; Arthur, C.; Post, G.R. A female infant with vomiting and failure to thrive. Clin. Pediatr. 2018, 57, 1004-1007. [CrossRef] [PubMed] 